\title{
Implementasi Kesehatan Dan Keselamatan Kerja Pada Atraksi Wisata Paralayang Di Desa Kutuh, Kabupaten Badung
}

Priesca a, 1, I Gede Anom Sastrawan a, 2

${ }_{1}^{1}$ priescationardi@gmail.com, ${ }^{2}$ anom_sastrawan@unud.ac.id

a Program Studi Sarjana Destinasi Pariwisata, Fakultas Pariwisata,Universitas Udayana, Jl. Dr. R. Goris, Denpasar, Bali 80232 Indonesia

\section{ABSTRACT}

This study aims to find out how the implementation of occupational health and safety of paragliding tourist attraction management system in Timbis Cliff, Kutuh Village, Badung Regency. The technique that used are observation technique, interview, literature study, and documentation study. While analysis technique that used are qualitative description.

The data on this research based on interview result from the informant, which is key informant or base informant on the main research field. The result of the interview is how the paragliding management implemented the occupational health and safety to the paragliding instructor team and the tourist, the factors that influenced the accidental issues, which is internal factors or external factors which is happened when the paragliding take place, also, how the management staff prevented and mitigated the accident when it happened. According to the data, the management staff implemented terms and condition before doing paragliding activity according to Standard Operational Procedure (SOP) like before being an instructor for paragliding, the person must have minimal Tandem 2 licence to be an instructor, maintenance and testing the equipment before using them, giving a short briefing to the tourist to prevent them doing anything forbidden and to avoid accident

Keywords: Occupational Health and Safety, Paragliding, Timbis Cliff, Standard Operational Procedure, Accident, Safety and Health

\section{PENDAHULUAN}

Kesehatan Keselamatan Kerja adalah faktor yang penting dalam setiap kegiatan yang dilakukan oleh semua pihak, sebab kecelakaan dapat terjadi kapan saja baik disengaja maupun tidak disengaja. Kecelakaan bisa terjadi karena faktor eksternal dan internal, dimana pada faktor eksternal kecelakaan terjadi akibat keadaan lingkungan dan alam sekitar, sementara pada faktor internal kecelakaan terjadi akibat kondisi jasmani dan rohani seseorang. Dalam dunia pariwisata kesehatan dan keselamatan kerja sangat penting karena melibatkan beberapa pihak didalamnya: Wisatawa (mancanegara atau domestik), karyawan, guide, perusahaan, pemerintah, dan masyarakat lokal. Dalam hal ini wisatawan maupun perusahaan yang menawarkan kegiatan wisata harus benar-benar memperhatikan keamanan pada jenis wisata yang ditawarkan karena berhubungan dengan kesehatan dan keselamatan wisatawan itu sendiri, dan pihak lainnya sebagai penanggung jawab dari kegiatan wisata yang ditawarkan. Karena itu, suatu kegiatan wisata yang dibangun oleh pihak swasta ataupun pemerintah harus menerapkan prosedur standarisasi kesehatan dan keselamtan kerja yang sudah sesuai dengan SOP yang ditentukan oleh pihak pengelola.

Wisata paralayang merupakan sebuah olahraga terbang bebas dengan menggunakan parasut. Para wisatawan lepas landas dari lereng bukit atau gunung dengan memanfaatkan angin dan hentakan kaki untuk membantu wisatawan lepas landas. Semua ini dilakukan tanpa bantuan mesin, namun hanya terfokus pada hembusan angin sehingga pihak pengelola wisata dan wisatawan itu sendiri harus memperhatikan SOP (Standard Operational Procedure) dan kesehatan keselamatan kerja selama atraksi wisata paralayang berlangsung sehingga dapat menghindari kecelakaan yang tidak diharapkan.

Desa Kutuh memiliki potensi wisata buatan yang bersifat olahraga ekstrim yakni paralayang. Paralayang yang ada di Desa Kutuh ini merupakan salah satu potensi wisata buatan di Desa Kutuh. Desa ini terletak di Kecamatan Kuta Selatan, Badung, Bali.

Kegiatan wisata paralayang di Desa Kutuh mempunyai tingkat kecelakaan yang tergolong rendah namun dalam penerapan konsep kesehatan dan keselamatan kerja masih membutuhkan peningkatan akibat adanya kekurangan petunjuk dan pengarahan yang diberikan oleh pihak instruktur dengan 
petunjuk dan pengarahan resmi yang diterbitkan oleh pihak pengelola wisata sehingga mengakibatkan kecelakaan selama jalan permainan wisata paralayang berlangsung masih dapat terjadi. Untuk itu dibutuhkan adanya analisis apakah pihak penyedia wisata paralayang Desa Kutuh sudah menerapkan konsep K3 yang berlaku atau belum menerapkan ketentuan tersebut secara menyeluruh.

\section{TINJAUAN PUSTAKA}

\subsection{Telaah Hasil Penelitian Sebelumnya}

Telaah penelitian sebelumnya sangat penting dilakukan untuk membandingkan antara penelitian sebelumnya dengan penelitian yang akan dilakukan berdasarkan focus penelitian sehingga tidak terjadi penelitian ganda, serta untuk mengetahui apa keunggulan dari penelitian yang sekarang dilakukan dibandingkan dengan penelitian yang sudah ada. Dalam penelitian yang dilakukan oleh Julius Simon (2016) yang dengan kesamaan focus dari penelitian ini adalah kesamaan dalam embahas bagaimana pola penerapan Kesehatan dan Keselamatan Kerja pada aktivitas wisata ekstrim. Telaah penelitian selanjutya yaitu oleh Wardani (2011) yang dalam penelitiannya adanya kesamaan fokus yakni menganalisis dan melakukan penelitian mengenai kegiatan wisata Paralayang. Telaah penelitian selanjutnya yaitu Kusuma dan Suryawan (2016) yang kesamaan fokus dalam penelitian ini adalah adanya kesamaan dalam pembahasan penerapan Kesehatan dan Keselamatan Kerja pada kawasan wisata.

\subsection{Landasan Konsep}

Dalam artikel ini menggunakan beberapa konsep diantaranya :

1. Konsep Kesehatan dan Keselamatan Kerja (UU No.1 Tahun 1970)

2. Konsep Atraksi Wisata (Yoeti, 1996)

3. Konsep Paralayang (KBBI)

\section{METODE PENELITIAN}

Penelitian dilakukan dikawasan wisata Desa Kutuh. Secara administratif Desa Kutuh terletak di Kecamatan Kuta Selatan, Kabupaten Badung, Provinsi Bali. Metode yang dipakai yaitu deskriptif kualitatif. Sumber data yang dipakai yaitu data primer tentang peran penyedia wisata dalam menerapkan Kesehatan dan Keselamatan Kerja (K3), data mengenai jenis peralatan penunjang kegiatan paralayang, dan pertolongan pertama apabila terjadi kecelakaan pada saat kegiatan berlangsung. Data sekundernya data monografi Kegiatan Paralayang di Desa Kutuh. Teknik pengumpulan data dengan wawancara penyedia wisata paralayang dan Instruktur paralayang dan wisatawan. Teknik analisis data adalah analisis deskriptif kualitatif.

\section{IV.HASIL DAN PEMBAHASAN}

\subsection{Atraksi Wisata Paralayang di Tebing Timbis, Desa Kutuh}

Lokasi paralayang berada di kawasan tebing di Desa Adat Kutuh, tepatnya di tebing Timbis. Wisatawan dapat menikmati atraksi wisata ini dengan membayar biaya sebesar USD 110 atau Rp.1.000.000,00 (Satu Juta Rupiah) untuk pengunjung lokal dan Rp.1.400.000,00( satu juta empat ratus ribu rupiah) untuk wisatawan mancanegara. Setelah membayar, pengunjung akan mendapatkan pemeriksaan kesehatan serta pengarahan dari instruktur mengenai tata cara pengunaan peralatan paralayang yang harus diwaspadai selama kegiatan paralayang sedang berlangsung. Selama sebulan, lokasi paralayang ini mampu mendapatkan 1000 wisatawan. Total tersebut mencakup wisatawan asing dan wisatawan lokal yang datang berkunjung. Jumlah wisatawan tersebut disampaikan langsung oleh pihak pengelola berdasarkan jumlah wisatawan yang berkunjung ke kawasan paralayang dalam sebulan. Kegiatan ini mendapatkan tanggapan positif dari masyarakat lokal di sekitar lokasi atraksi wisata serta penikmat atraksi wisata paralayang itu sendiri. Pemandu kegiatan paralayang harus memiliki lisensi terlebih dahulu untuk dapat memandu kegiatan wisata ini. Mereka harus memiliki lisensi T2 atau Tandem 2 yang didapatkan dari FASI ( Federasi Aero Sport Indonesia) untuk memperoleh izin mengoperasikan dan membawa wisatawan dalam penerbangan atraksi paralayang. Dengan demikian wisatawan dapat merasa aman karena kesigapan karyawan maupun pemandu wisata dalam mempersiapkan segala hal sebelum melakukan kegiatan paralayang. Selama berlangsungnya kegiatan paralayang, pihak pengelola menjelaskan bahwa selama ini belum pernah terjadi kasus kecelakaan yang 
menimpa karyawan maupun wisatawan. Namun, pihak pengelola tetap memberikan jaminan asuransi kesehatan dari pihak desa adat dan pihak Jasa Raharja demi menjamin keselamatan wisatawan yang datang berkunjung untuk menikmati atraksi wisata paralayang tersebut. Mengingat olahraga paralayang termasuk dalam jenis olahraga ekstrim dan berbahaya.

\subsection{Sejarah Berdirinya Usaha Wisata Paralayang}

Sejarah lokasi paralayang di Pantai Pandawa dimulai dari penemuan sebuah tebing dekat dengan lokasi pantai oleh seorang wisatawan Prancis bernama Berna pada tahun 1993, dimana beliau memberi nama tebing ini Tebing Timbis. Penggunaan tebing ini berkembang dari tahun ke tahun sehingga menjadi pusat atraksi wisata paralayang yang sekarang dikenal masyarakat pada tahun 2015 setelah pengelolaan diambil alih oleh Desa adat Kutuh melalui Unit Usaha Atraksi Paragliding dan ditata dengan bantuan dari Federasi Aerosport Seluruh Indonesia (FASI) Provinsi Bali. Kegiatan Paralayang di tebing ini sudah memecahkan beberapa rekor muri pada tahun 1997,2007, 2008, 2009 dan di tahun 2016 sebagai penyelenggara kegiatan perlombaan paralayang terbesar se-Asia

\subsection{Struktur Organisasi Pengurus Atraksi Wisata Paralayang}

Usaha wisata paralayang ini memiliki struktur organisasi yang berada langsung dibawah pengaruh Desa Adat Kutuh. Organisasi tersebut terdiri dari 18 orang anggota dan 7 orang crew yang bertugas langsung dalam pengelolaan wisata paralayang. Struktur organisasi antara lain:

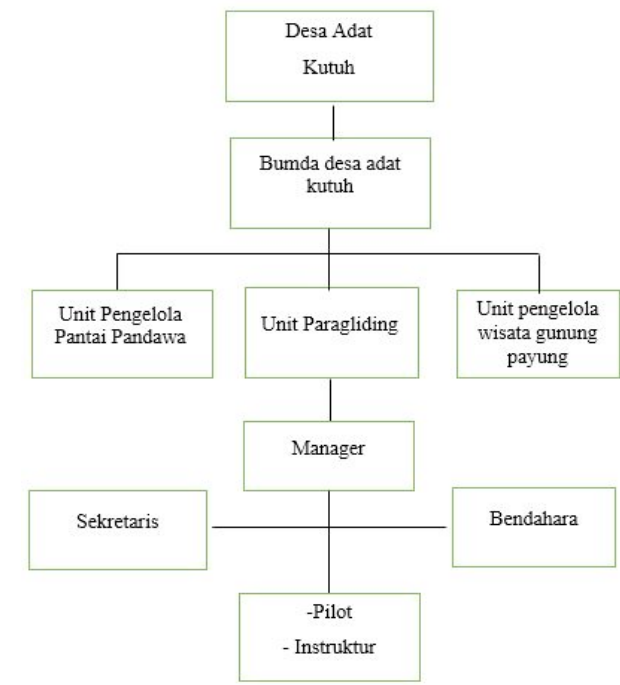

Gambar 4.1 Struktur Organisasi Paralayang Desa Adat Kutuh

(Sumber: Dokumentasi Penelitian)

4.4 Faktor-Faktor Yang Mempengaruhi Terjadinya Kecelakaan

Hal ini dapat terjadi akibat kurangnya rasa waspada manusia terhadap diri dan sekitarnya, sehingga kecelakaan dapat terjadi kapan saja dalam kegiatan yang dilakukan manusia, tak terkecuali saat sedang berwisata. Kecelakaan pada wisata rentan terjadi akibat lalainya manusia terhadap larangan dan peraturan yang sudah diterapkan serta kondisi fisik yang mungkin kurang mendukung pada saat berwisata sehingga kecelakaan dapat saja terjadi. Faktor-faktor yang dapat memicu kecelakaan dapat berupa:

\subsubsection{Faktor Internal}

Di bawah ini merupakan faktor internal yang memicu kecelakaan pada kegiatan Paralayang di Desa Kutuh.

\section{a. Faktor Usia}

Usia rentan menjadi alasan utama terjadinya kecelakaan akibat keterbatasan seseorang dalam melakukan segala hal dari biasanya. Faktor usia menghambat laju stamina atau kondisi fisik seseorang dalam bekerja, sehingga seseorang mudah merasa lelah. Rasa lelah tersebut akan berakibat fatal karena akan membuat seseorang kehilangan focus dalam bekerja oleh karena itu dalam kegiatan paralayang, Instruktur yang merasa lelah dihimbau untuk tidak melakukan penerbangan karena memiliki resiko tinggi akan mengakibatkan kecelakaan yang membahayakan nyawa wisatawan.
1.) Faktor Penyakit 
Wisatawan dan Instruktur yang memiliki penyakit atau dalam kondisi sakit dilarang untuk mengikuti kegiatan paralayang karena dapat menimbulkan resiko tinggi kecelakaan fatal, terutama jika wisatawan atau instruktur memiliki penyakit yang berhubungan dengan jantung, serta memiliki riwayat penyakit lainnya seperti epilepsy, Tekanan darah rendah atau tinggi, serta penyakit lainnya yang memberikan dampak fatal lainnya.

\section{2.) Faktor Peralatan}

Peralatan safety serta peralatan utama untuk paralayang seperti parasut utama, harness, parasut cadangan, radio.helm, windmeter, dan variometer harus diperiksa kelayakannya sebelum digunakan untuk melakukan kegiatan paralayang apakah masih layak untuk digunakan atau tidak. Sebelum kegiatan paralayang dimulai, wisatawan dihimbau mengenakan peralatan safety seperti: helm, sepatu khusus, parasut dan sarung tangan sesuai dengan instruksi dan SOP yang diinstruksikan oleh pihak pengelola terhadap wisatawan agar dapat meminimalisir cedera apabila kecelakaan terjadi selama kegiatan paralayang berlangsung.

\section{3.) Faktor Kelalaian}

Faktor Kelalaian terjadi akibat beberapa kemungkinan, salah satunya adalah faktor kelalaian yang ditimbulkan wisatawan akibat tidak mendengarkan arahan dan instruksi dari pengelola wisata atau melakukan kegiatan diluar arahan instruktur sebelum penerbangan, selama penerbangan dan pada saat akan mendarat. Seperti:

\subsubsection{Faktor Eksternal}

Adapun faktor eksternal yang memicu kecelakaan pada kegiatan Paralayang di Desa Kutuh adalah faktor lingkungan yang menjadi salah satu penyebab utama kecelakaan dalam aktivitas kegiatan paralayang, Karena wisata ini menggunakan angin sebagai sumber energi utamanya, maka pihak pengelola harus terus memantau dan mengamati tekanan angin yang berhembus di sekitar kawasan paralayang. Apabila hembusan angin lebih kencang dari rata-rata, maka penerbangan akan dilarang hingga tekanan angina kembali normal.

Hembusan angin yang normal untuk melakukan penerbangan adalah $15-20 \mathrm{Km}$ per jam, sementara hembusan angin yang berbahaya berada pada titik lebih dari $25 \mathrm{Km}$ per jam . Selain hembusan angin, faktor cuaca juga menjadi salah satu penyebab kecelakaan tertinggi. Kegiatan paralayang tidak diperbolehkan untuk dilakukan apabila adanya tanda-tanda akan turun hujan ataupun sedang berada pada waktu malam hari karena selain berbahaya, parasut dan peralatan lainnya tidak dapat digunakan akibat tekanan udara yang berbeda dengan saat siang hari. Selain itu, beberapa jenis awan berpotensi menyebabkan resiko kecelakaan seperti awan cumulus nimbus (CB) yang memiliki angina berkecapatan lebih dari 10 knots yang tentunya berbahaya bagi penerbang paralayang.

\subsection{ImplementasiKesehatan dan Keselamatan Kerja (K3) pada Karyawan atau Pemandu Wisata}

\subsubsection{Implementasi Kesehatan dan Keselamatan Kerja (K3) pada Karyawan}

Penerapan K3 yang paling utama kepada pihak pengelola adalah dengan memenuhi syarat-syarat utama demi keselamatan instruktur dan pemandu wisata pada aktivitas wisata paralayang itu sendiri.

Berdasarkan hasil wawancara dengan pihak pengelola wisata, berikut adalah persyaratan yang diberikan kepada karyawan penyedia wisata paralayang Desa Kutuh selama kegiatan berlangsung:

1) pihak pengelola wisata paralayang harus memiliki kondisi fisik yang sehat, tidak memiliki penyakit khusus dan tidak memiliki kondisi cacat baik itu cacat fisik maupun cacat mental.

2) para Instruktur atau pemandu wisata pada aktivitas wisata paralayang harus memiliki lisenssi minimal Tandem 2 (T2) yang dikeluarkan oleh pihak Federasi Aero Sport Indonesia (FASI) sebelum dapat mengoperasikan keberlangsungan kegiatan paralayang;

3) memberikan asuransi dan jaminan kesehatan serta keselamatan kepada setiap orang yang terlibat dalam penyelenggaraan kegiatan paralayang baik itu pengelola maupun instruktur paralayang;

4) setiap instruktur yang akan menjadi pemandu bagi wisatawan harus menggunakan peralatan keamanan (Safety set). 
Instruktur yang akan menjadi pilot selama paralayang umumnya memiliki tingkat lebih dari Tandem 2 (T2), dimana tingkat Tandem 2 adalah syarat minimal yang dibutuhkan oleh seorang instruktur untuk dapat mengoperasikan parasut paralayang. Para calon instruktur paralayang sebelumnya harus menjalankan pelatihan dari FASI yang berupa pelatihan fisik maupun mental dan diwajibkan melewati beberapa tahap untuk mendapatkan lisensi tersebut. Beberapa tahapannya sebagai berikut:

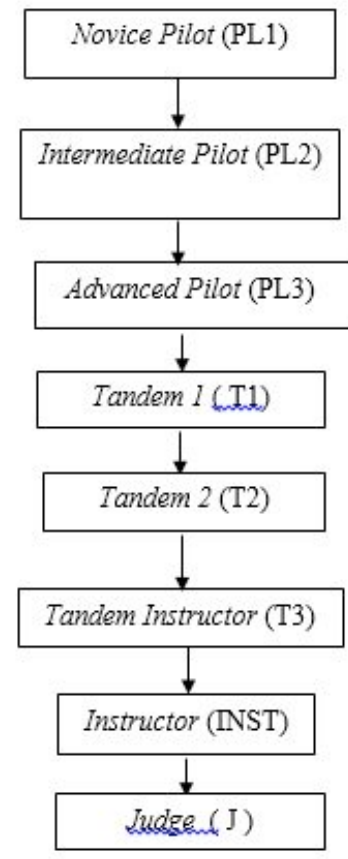

Gambar 4.2 Tahapan lisensi calon Instruktur Paralayang

(Sumber: Pengelola Wisata Paralayang Kutuh)

\subsubsection{Penerapan Kesehatan \\ Keselamatan Kerja Pada Wisatawan}

dan

Penerapan K3 kepada wisatawan adalah prioritas utama dari pihak pengelola wisata, sebagai bentuk perlindungan terhadap keselamatan jiwa wisatawan selama kegiatan paralayang berlangsung mengingat paralayang termasuk dalam jenis olahraga ekstrim. Wisatawan akan diberikan syarat khusus untuk dapat berpartisipasi dalam mengikuti kegiatan paralayang, sehingga kejadian kecelakaan dapat dihindari serta meminimalisasi angka kecelakaan yang terjadi. Adapula syarat-syarat yang diberlakukan kepada wisatawan adalah sebagai berikut:
1.) Wisatawan akan diberikan briefing mengenai peraturan yang tidak boleh dilanggar dan arahan dalam melakukan aktivitas paralayang.

2.) Usia yang diperbolehkan untuk mengikuti kegiatan paralayang maksimal berusia 60 tahun.

3.) Wisatawan tidak boleh memiliki penyakit terutama penyakut jantung yang kronis

4.) Wisatawan diwajibkan memiliki fisik yang berada dalam kondisi sehat dan siap melakukan aktivitas paralayang

5.) Wisatawan yang memiliki phobia ketinggian tidak dianjurkan untuk mengikuti kegiatan paralayang

6.) Berat badan maksimal wisatawan tidak boleh lebih dari $90 \mathrm{Kg}$.

7.) Wisatawan wajib menaati SOP yang sudah diarahkan, dan menggunakan peralatan pengaman diri seperti helm, sepatu, dan harness ( tempat duduk) untuk keselamatan selama melakukan aktivitas

Sebelum dilaksanakannya kegiatan paralayang, Briefing adalah hal penting yang harus diberikan instruktur kepada wisatawan.

Briefing dilakukan untuk menghindari kecelakaan yang kemungkinan akan menimpa wisatawan apabila adanya kesalahan dari minimnya informasi tentang aturan yang dilakukan selama aktivitas paralayang.

Instruksi yang diberikan oleh instruktur kepada wisatawan yang akan melakukan kegiatan wisata paralayang adalah:

1.) Mengkonfirmasi ulang apakah wisatawan sudah siap untuk melakukan kegiatan paralayang, baik secara jasmani dan rohani. Serta mengkonfirmasi ulang kesungguhan wisatawan untuk melakukan kegiatan paralayang

2.) Memberi arahan dalam menggunakan peralatan keselamatan diri

3.) Memberikan instruksi dan mengajarkan cara lepas landas, hal hal yang dapat dilakukan selama terbang dan mengajarkan cara landing atau mendarat.

4.) Memberikan pengarahan kepada wisatawan agar tidak panik dan tetap tenang selama penerbangan 


\subsection{Analisis Penerapan Kesehatan dan Keselamatan Kerja pada karyawan dan wisatawan yang menggunakan atraksi wisata paralayang}

Meskipun dalam penerapan kesehatan dan keselamatan kerja pada atraksi wisata paralayang di Desa Kutuh sudah tergolong cukup baik, namun masih ada kejanggalan dan kurang lengkapnya persyaratan yang diberlakukan oleh pihak pengelola sehingga masih dapat memungkinkan terjadinya kecelakaan yang membahayakan pihak karyawan maupun wisatawan. Berdasarkan persyaratan yang diberlakukan pihak pengelola terhadap karyawan dan instruktur kegiatan paralayang di Desa Kutuh, terkadang adanya kesalahan pada instruksi terhadap wisatawan asing akibat adanya kesalahan dalam pengucapan bahasa asing sehingga terkadang wisatawan asing akan melakukan kesalahan akibat adanya kesalahan instruksi dari instruktur, kemudian pada persyaratan yang diberlakukan kepada wisatawan, adanya sedikit kekurangan pada persyaratan untuk menggunakan atraksi wisata paralayang, diantaranya tidak tercantumnya usia minimal untuk wisatawan untuk dapat menggunakan atraksi wisata ini. Kemudian lokasi ini juga turut menyediakan pemeriksaan fisik namun dalam waktu yang tidak menentu, sebab terkadang fasilitas ini tersedia, terkadang tidak tersedia di lokasi tempat atraksi wisata paralayang ini berlangsung. Kemudian meskipun pihak pengelola menyediakan ruangan penannganan medis, lokasi ruangan ini tergolong sangat jauh sehingga penanganan medis saat terjadi kecelakaan dapat terhambat.

Meskipun pesyaratan dan peraturan yang berlaku disampaikan dengan jelas secara lisan, namun lokasi ini tidak menuliskan peraturan dan persyaratan yang jelas secara tertulis, sehingga masih banyak wisatawan melakukan hal hal yang seharusnya dilarang oleh pihak pengelola wisata, seperti menerbangkan parasut paralayangnya menuju tebing yang merupakan kawasan suci karena adanya Pura Gunung Payung meskipun sudah diberikan bendera bertanda khusus sebagai pengingat dan larangan untuk melintas maupun menerbangkan parasutnya tidak sesuai instruksi yang diberikan oleh instruktur sehingga kerap terjadinya kecelakaan yang tidak diharapkan.

\subsection{Penanganan dan Pencegahan Kecelakaan}

Sebagai pengelola wisata olahraga ekstrim, para pengelola harus siap dalam mengantisipasi dan menangani kecelakaan yang terjadi dalam kegiatan wisata yang mereka kelola. Karena kecelakaan bukan hanya memberikan dampak terhadap kondisi fisik maupun mental, namun juga memberikan dampak kerugian baik secara ekonomi maupun citra pengelola sebagai penyedia wisata. Untuk dapat menanggulangi kecelakaan tersebut, perlu adanya pencegahan dan penanganan untuk mengantisipasi kecelakaan tersebut, diantaranya adalah:

\subsubsection{Pencegahan}

Agar dapat memberikan rasa nyaman terhadap wisatawan selama kegiatan paralayang berlangsung, perlu adanya kesigapan dari pihak pengelola untuk memperhatikan segala sesuatu dimulai dari hal paling dasar seperti pengecekan kelayakan peralatan sebelum melakukan penerbangan, kondisi kesehatan instruktur dan kelengkapan peralatan paralayang hingga hal-hal penting sebelum melakukan paralayang seperti memastikan sudah dilakukannya briefing, pengecekan kecepatan angin dan cuaca, kondisi lingkungan, dan tersedianya peralatan Pertolongan Pertama Pada Kecelakaan ( P3K). Dengan demikian kecelakaan dapat diminimalisir oleh pihak pengelola. Beberapa kegiatan pencegahan yang dapat dilakukan oleh pihak pengelola diantaranya adalah:

1.) Mempelajari kondisi sekitar ataupun lokasi tempat aktivitas wisata, baik dari segi lingkungan maupun segi lokasi.

2.) Instruktur harus memiliki lisensi dari FASI ( Federasi Aero Sport Indonesia) dan memberikan instruksi yang benar kepada wisatawan sehingga tidak adanya misinformation atau kesalahan dalam pemberian informasi sehingga menimbulkan kecelakaan yang tidak diinginkan

3.) Wisatawan yang memiliki penyakit jantung atau penyakit lainnya tidak diizinkan mengikuti kegiatan paralayang untuk menghindari resiko kecelakaan, sementara bagi wisatawan yang hendak melakukan 
kegiatan paralayang tidak boleh melakukan hal hal yang dilarang selama penerbangan berlangsung sesuai dengan peraturan yang disebutkan oleh instruktur dalam briefing.

\subsubsection{Penanggulangan}

Meskipun sudah dilakukannya beragam pencegahan untuk menghindari kecelakaan, namun kecelakaan tetap memiliki potensi untuk tetap terjadi, tak terkecuali dalam kegiatan paralayang di tebing Timbis, Desa Kutuh. Pihak pengelola menyediakan asuransi jaminan kesehatan kepada wisatawan, dimana asuransi tersebut diberikan oleh pihak Desa Kutuh yang bekerja sama dengan Jasa Raharja. Selain itu pihak Desa Kutuh juga berkerja sama dengan Rumah Sakit Surya Husada apabila terjadi kecelakaan fatal, dengan dilengkapi dengan ambulans yang siap siaga. Pada lokasi paralayang, disediaan kotak perlengakapan P3K (Pertolongan Pertama Pada Kecelakaan) yang berisikan obat merah, kapas, kasa atau perban, pinset, perekat, alcohol dan minyak kayu putih. Apabila kecelakaan terjadi, pihak pengelola akan melakukan pemberhentian sementara pada kegiatan paralayang dan memprioritaskan keselamatan wisatawan atau instruktur yang mengalami kecelakaan untuk diberikan tindakan lebih lanjut berupa pemberian pertolongan pertama.

\section{PENUTUP}

\subsection{Simpulan}

Berdasarkan pembahasan diatas maka dapat dbentuk simpulan yakni aktivitas paralayang yang dilakukan oleh Desa Kutuh memiliki tingkat kecelakaan yang rendah, namun kecelakaan masih kerap terjadi akibat perubahan arah angin dan cuaca yang kerap tidak stabil, sehingga dibutuhkannya instruksti dan penanganan kesehatan dan keselamatan kerja yang ketat pada pihak karyawan maupun wisatawan. Persyaratan yang diberikan oleh pihak pengelola sudah cukup jelas, namun masih adanya kekurangan informasi sehingga wisatawan masih dapat melakukan hal hal yang terlarang selama kegiatan wisata berlangsung seperti tidak adanya batas usia minimal dan tidak adanya pemeriksaan fisik secara rutin selama 1 hari kegiatan sehingga masih ada peluang terjadinya kecelakaan. Kemudian kondisi ruangan medis yang jauh mengakibatkan adanya keterlambatan dalam penanganan kecelakaan apabila terjadi Dalam hal komunikasi, pihak pengelola hanya menyediakan penyampaian informasi secara lisan, namun tidak menyediakan secara tidak tertulis sehingga dapat terjadinya miscommunication antar wisatawan dengan instruksi sehingga wisatawan baik domestik maupun mancanegara masih kerap melakukan kesalahan yang dapat mengakibatkan kecelakaan fatal.

\subsection{Saran}

Adapun saran yang diberikan sebagai berikut:

1.) Untuk pihak pengelola perlu menyediakan ruangan medis yang lebih dekat dengan lokasi penerbangan paralayang, Sehingga apabila terjadi kecelakaan pada saat kegiatan, korban kecelakaan dapat lebih cepat mendapatkan penanganan medis pertama sebelum dibawa ke Rumah Sakit;

2.) Disediakan papan prosedur $K 3$ dan prosedur penggunaan peralatan keamanan di sekitar lapangan paralayang;

3.) Pihak pengelola harus merawat dan menjaga peralatan paralayang agar selalu dalam kondisi yang baik dan layak untuk digunakan;

4.) Bagi wisatawan diharapkan agar selalu mengikuti dengan baik arahan yang diberikan oleh instruktur atau pemandu wisata. Kemudian wisatawan diharapkan mentaati peraturan-peraturan yang telah dibuat oleh pihak pengelola wisata paralayang serta lebih mawas diri mengenai kondisi tubuh dan kesehatan agar dapat menghindari kecelakaan yang tidak diharapkan.

5.) Bagi wisatawan internasional diharapkan untuk memastikan kembali pesyaratan dan instruksi yang diberikan oleh pihak instruktur apabila adanya ketidakjelasan dalam pemberian informasi dan instruksi.

\section{DAFTAR PUSTAKA}

Yoeti, Oka A. 1996. Pengantar Ilmu Pariwisata, Edisi pertama, Angkasa: Bandung.

Bennet, Silalahi. 1995. Manajemen Keselamatan dan Kesehatan Kerja, Jakarta: PT. Pustaka Binaman Pressindo 
Simon, Julius. 2016. Penerapan Keselamatan dan Kesehatan Kerja Pada Aktivitas Wisata Berenang Bersama Ikan Hiu ( Swim With Shark) di Pulau Seranan, Denpasar Selatan. Bali: Universitas Udayana. (Skripsi)

Wardani, Nila.2011. Pengembangan Objek Wisata Paralayang Berdasarkan Kajian Geografis di Kota Batu. Malang. Skripsi, Jurusan Geografi, FIS, Universitas Negeri Malang. (Skripsi)

Kusuma, Satwika Wiguna. Suryawan, Ida Bagus. 2016. Penerapan Keselamatan dan Kesehatan Kerja Balawisata di Pantai Kuta. Bali: Universitas Udayana 